\title{
Correctness of the Subtitled Expressions in Context: The Translator in Film Making Process
}

\author{
Christopher Chinedu Nwike \\ Department of Linguistics, Igbo and Other Nigerian Languages, University of Nigeria, Nsukka, Nigeria \\ Christopher Uchenna Agbedo \\ Department of Linguistics, Igbo and Other Nigerian Languages, University of Nigeria, Nsukka, Nigeria
}

\begin{abstract}
This paper hinges on the correctness of the subtitled expressions in context: The translator in film making process. The objective of the study is to ascertain the correctness of subtitled expressions in context, in the movie used for the study. It focuses on fishing out the wrong subtitled expressions in context of discourses in the movie Onye Bu Nna M. The study sees subtitle as substituting the vocal utterances in a filmic material to a written equivalence on the screen of the television. The discredit of subtitle in the Nollywood touches the areas of wrong expression of a particular utterance in a movie into another language through subtitle and non alignment of the spoken utterances with its subtitled equivalences. However, all these formed the problem of the study. This study adopts the formal and dynamic equivalence of Nida as well as Gottlieb's strategies of subtitle as the frameworks of the study in order to effectively carry out this research. This research adopts the emergent design approach in its methodology. The study reveals that if information is subtitled well with the correct tenses in context, there will be no misinterpretation of ideas or information by the target audience.
\end{abstract}

Index Terms - subtitles, subtitle strategy, Nollywood and correct expressions in context

\section{INTRODUCTION}

Before and after the invention of subtitle, both the actors and the producers of home movies as well as musical videos have been working seriously, towards making their products familiarized to the foreign and the local viewers. This process is what Uchenna (2007) says that it is done in a local way. He further added that Nigerians have a particular way of approaching their movies, and this is done by seeking not to translate the content and context of the movie but to comment on the important moments, thereby facilitating viewers' understanding. According to Nwatu (2017), in the act of running the commentary in the viewers' language, it is not always suitable for mixed audiences because, those who have the knowledge of the original language can actually see those live commentaries as distraction, and in the process, the essence of bridging the language gap is cut off. This breach in relating the information to the target audience will be obvious because, some diasporic Nigerians do not patronise films produced only in Nigerian languages. So, due to the widening circulation of Nollywood Igbo films and to avoid much decline in the use of the Igbo language among the diasporic communities, the need for another solution came - subtitles, in order to enhance patronage and audience's reception of audiovisual materials with correct expressions in context, in the Nollywood movies, the Igbo example. In subtitles, different languages are used throughout the world to communicate ideas, beliefs, intentions, actions and feelings. According to Nwike (2019), with the mass media and internet, this interaction is occurring faster and more frequently with every passing second. For specialized areas like linguistics, mathematics or computer programming, languages are used more often in an effort to create much desire and need in order to come up with new processes and systems towards educating people. However, the adopted target language in this study is the English language where its tenses and grammar use in the selected movie are the focus of this study - subtitling the correct expression in context. Based on this, the study is involved with the elements of a sentence which are the subject, verb, object, complement and adverbials. From the forgoing, the problems of poor transfer of the subtitles are greatly hinged on the past mentioned outlines as the expressions in the target language is rendered through them at different points. However, Christopher (2014) is of the view that one who lacks the knowledge of the grammar of the target language will actually find it hard transferring the original meaning of the vocalized utterances, as the translator who is not competent in the target language according to Bilal (2016) will produce wrong subtitles that will not be functional in the target language as original. The transferring exercise is supposed to be done by the translator(s) that knows the culture and the language of the both languages, as the one who is not readily available in the languages competence and performance will find the process of rendition tasking.

During the transferring exercise, the translator who renders meaning from one language to another should understand the possible rules of the target language (Nwike, 2015). For Tim, Wilfried, Fred and Nadira (2017), they believed that subtitle is spoken and written based. In this study, let us call it spoken-written because, it is involved with the spoken utterance of an actor or the source speaker while its target equivalence will be written on the below part of the television or cinema alongside with the spoken utterances. Based on this, one who subtitles from a particular language of any 
filmic type should be able to understand all the things that make up a language structure of the target language. Since focus is on wrong expressions that are subtitled in the English, it is pertinent that the translator, who subtitles, understands the basic grammatical units of the English language as it will help him or her to clearly transpose the original information in the target language because the sentences will be meaningful ones. The translator who subtitles from Igbo to English should understand the letters of the English language, and the vowels. Based on this, in trying to subtitle well into the English language, the translator should understand that words functions pertinently in the units of the English language. However, a word converts the group of letters into a meaningful one because; words are group of letters with a meaning. For instance, in the word of English language, a word like 'chair' is having five letters c-h-a-i-r and with this, the word is formed with collective forms of few letters. Based on this, it is important that a translator who subtitles from the Igbo to the English language should know at least 30,000 words to become a good communicator in the English language, as it will help the translator to flow well during the subtitle exercises. Till a translator masters that much of words and the basics of the English language, he or she have to keep on learning so that the translator's language skill will get sharpened day by day and fall alongside with the active vocabulary of the target language. This is to say that becoming thorough with the basics of the English language is a matter of practice and performance.

In line with the above information, the knowledge therein will assist the translator during the information transfer. The words can be used in different forms as it can be used to form a phrase which is another important unit in the English language. A phrase can be called a group of words without a subject and a verb. A subject is what the sentence is about, while the verb tells something about the action of the subject in a sentence. Some of the phrases of the English language go thus: the fair police man, the yellow dress, to dress well, etc. Again, there are nominal or noun phrases. For instance, the phrases have nouns as the most important words in the used examples thus the fair police man, where the noun "police" is the most important word in that phrase. Another example is 'the yellow dress.' More so, there is a verb phrase and it is exemplified as thus, 'to dress well' performs the function of a verb phrase as the both examples occupy the position of the subject in a sentence and also their grammatical functions in a sentence. Based on this, a translator should understand what a phrase is as it will help him to transfer better during the process of rendition. A good translator should be able to differentiate between phrases and a clause. A clause can be called a group of words with a subject and a predicate having a meaning. For instance, you are my worst enemy, when the car arrived, etc. In the same line with this, a good translator should understand clearly that when a clause suggests a complete meaning, it will be a main clause, as 'you are my worst enemy' suggests a complete meaning and it is a main clause. In line with the following, it is clear that all languages have its own phonotactics and mechanics. When a translator lacks the basic knowledge of the rule that guides a particular language and culture, his subtitles in the target language will be faulty. Upon this discourse based on the focus of the study, it is pertinent to state clearly that the wrong expressions in context that this exercise is studying are hinged on the sentence structures. A sentence is the form which carries all the units of the English since it is a group of clauses that conveys a complete meaning. For instance, 'when you come to our house, please, bring that dress. In this sentence, there exist of one main clause and one subordinate clause. Again, she is smart but she gossips. From this sentence, it can be discovered that it has only two main clauses. However, the wrong expression in the context of a particular usage has posed lots of challenges in the Igbo subtitled movies of the Nollywood industry owned by the Nigerians.

From the above, Nigerians became enthusiastically moved and equally fascinated by the cinema after the first film entitled The coronation of King Edward VII at Westminster which was shown in Lagos in 1903 and eventually became a welcome relief to the dull monotony of the town. By 1935, Aderinokun (2005) states that the Edgar Rice Burroughs film Sanders of the River, which was partly shot in Nigeria featured the Nigerian Orlando Martins of 1899 - 1985, who acted alongside with Paul Robeson from America and therefore began to create the sensitivity around film making in Nigeria. Based on this, Aderinokun (2005) says that in the 1950s and 1960s, there were more than one hundred theatre troupes in the Yoruba region alone, travelling from village to village for evening entertainments. Some of the troupes include Wole Soyinka's Mbari Mbayo cultural group and Hubert Ogunde's troupe. Within the period of 1980s, some of the stage presentations began to use short film projections to portray the Splendor of kingly courts, magical transformations, The intrigue of good and evil spirits, and The outrageous wealthy living of the new Nigerian rich. However, by the middle of 1980s, when every State has gotten their own television and radio broadcasting stations, laws then limited foreign television contents on the media schedules, and on this, the producers of television programmes started featuring local popular theatrical arts more than their foreign alternatives. So, in line with the success attained so far, the broadcast later lead to the inexpensive video technology of the late 1980s that transformed the practice of producing and consuming films, and the stage presentations moved totally into video film production. Based on this, people loved filming to live theatres and so, Nollywood was created with the application of subtitles after few years of emergence in order to help a non speaker of a particular native language to follow up with any movie made available by the entertainment industry. Due to no experts and lack of competent hand or what I will call over-sabi by some of the staff of the entertainment house, there abound lots of discredits to much of the produce of the Nollywood house, the Igbo example. Herein, over-sabi is used in the sense of assuming to know much while you actually don't know anything. This discredit touches the areas of wrong expression of a particular utterance in a particular movie into another language through subtitle, lack of proper punctuations, capitalization, and finally, a non alignment of spoken utterances with its subtitled equivalences. However, all these formed the problem of the study, although, the essence of 
this research aims at studying the correctness of subtitled expressions in context: The translator in film making process in the selected Igbo movie, and providing solutions on how to go about the encountered problems during subtitle processes. Supposedly, information transfers are done by translators, and this very transfer can be textual or paratextual. Textual transfers are the book form of renditions while paratextual in this study is taking to be a non book transfer such as media or audio visual translation which subtitle is one. However, subtitles are done in the process of filming and so, the translator acts out the function of subtitling in the film making process. His roles in subtitling correct expression in context make the target information original in the target language. The role of a translator is encompassing in the sense that he aids in bringing out the authenticity of the spoken source information in the target language (Magdalene and Agnieszka, 2020). Also, it makes the subtitle original as well as making the intended information to be properly passed, especially, in the context in which it is used. Most times, it is discovered that some subtitled movies loses its taste because of wrong transfer of expression in context, and this on the contrary, will not allow a foreign language learner of Igbo, or those who suffer hard of hearing or hearing impaired patients to follow up the intended message of the home made movies. This will in other words make the essence of the subtitle to be lost and misappropriated in the process. However, by the end of this study, the exercise shall be of help to the Igbo media house of Nollywood industry as it will expose them with the right methodologies to adopt in order to have good rendition in their subtitles. While in academics, it will add to the existing literatures in scholarship as it will assist future researchers during their studies.

\section{THEORETICAL STUDIES}

The study of Nida (1964) came up with the formal and dynamic equivalence in translation. The formal equivalence of translation tries to remain as close to the original text as possible without adding the translator`s ideas and thoughts into the transferred information. This type of translation is more literal in nature and so, the more literal the translation seems, the less danger there is of corrupting the original message, hence, it can be called a word for word translation. However, there is a unique feature that is attached with this form of translation. The uniqueness assumes a moderate degree of familiarity with the subject matter on the part of the reader. However, a clear excerpt can be gotten from the translation done in the King James Bible Version and the English Standard Bible Version. On the other hand, the dynamic equivalence is an approach to translation where the original language is rendered thought for thought instead of word for word as it appeared in a formal equivalence. Based on this ground, a dynamic equivalence is involved with taking each sentence thought for thought from the original text and renders it into a sentence in the target language in a way that it conveys sameness in meaning, but does not necessarily use the exact phrasing of the original. The idea behind this dynamic equivalence is to improve readability by rephrasing constructions that could be confusing when literally translated. This is to say that it retains some faithfulness to the original text rather than creating a complete paraphrase. Again, the dynamic equivalence sacrifices faithfulness to the original text in order to achieve a more natural translation. It is equally formed in order to be used when the readability of the translation is more important than preserving the original wording. A dynamic equivalence is useful when the original language is very different from the target language because, it helps in understanding better the literal translation. Categorically, dynamic equivalence is almost used in the context of Bible translations. This instance can be seen in the New Living Translation Bible while in the New International Version, its translation tries to strike a balance between dynamic and formal equivalence. In accordance with this, in some places, it will adopt a dynamic equivalence translation while at some point, it uses a formal equivalence. Based on this, Nida (1964) definitions of formal and dynamic equivalence are involved with the cultural implications for translation. Upon this, Nida states that a gloss translation is typified a formal equivalence where form and content are reproduced as faithfully as possible and the target language audience is able to comprehend very well as much as he can of the customs, manner of thought and means of expression of the source language context. On the contrast, a dynamic equivalence works towards relating the receptor to modes of behaviour that is relevant within the context of the reader's own culture without insisting that he understand the cultural patterns of the source language context.

From the above, there are individual problems in the two forms of equivalences, and the problems vary in scopebased on the cultural and linguistic gap between the two languages concerned. In connection to this, Nida made reference to a bible translation where Lamb of God is transposed as Seal of God for the Eskimos. This is because; the lamb does not imply innocence in their culture. He further asserts that in a situation like this, a formal equivalence does not mean anything in a different culture and so, a dynamic equivalence is very pertinent in this type of translation. Irrespective of the situation where this kind of translation can be applied, some people still believe that the literal form of translation is the best. Due to this, on the contrast of formal and dynamic equivalence, it is highly believed that people who believe that literal translation is closer to the original have much preference over the formal equivalence while on the contrast, people that prefer a dynamic equivalence will feel that such translation allows people to understand better the original information. So on the contrastive analysis of the two forms of translation according to Nida (1964), there are differences with the formal equivalence and dynamic equivalence. The issue with the former is that it might demand too much of some readers while in the later, the reader encounters the text with most of the decisions already made and must assume that the work of the translator(s) are not prejudicial. In filmic study, Gottlieb (1992) came up with the translation strategies for film subtitles, and they are: 
i. Expansion: This is used when the original requires an explanation because of some cultural nuances that are not retrievable in the target language.

ii. Paraphrase: It is used in cases where the phraseology of the original cannot be reconstructed in the same syntactic way in the target language.

iii. Transfer: This involves translating the source text completely and accurately.

iv. Imitation: This is maintaining the same forms, typically with names of people and places.

v. Transcription: It is used in the cases where a term is unusual even in the source text.

vi. Dislocation: This is adopted when the original employs some sort of special effect.

vii. Condensation: This involves the shortening of the text in the least obtrusive way possible.

viii. Decimation: This is an extreme form of condensation where perhaps for reasons of discourse speed, even potentially important elements are omitted.

ix. Deletion: This involves the total elimination of parts of a text.

x. Resignation: This is used when no translation solution can be found and meaning is inevitably lost.

From the above outlines, these strategies are used by translators to handle different subtitle problems. Upon this, Nwatu (2017) asserts that Gottlieb provided a general typology of the various forms of audiovisual translation. However, condensation is different from paraphrase because, condensation compresses the message while the paraphrase quickly rearranges the sentential structures. Again, condensation precedes and necessitates paraphrase. The implication according to Gottlieb (1992) is that by using the subtitle strategies on the videos, it will be shown to have more frames subtitles than it actually has. This is to say that a particular frame reflects more than one strategy at once. Summarily, the work of Gottlieb maintains that translators who set to subtitle must use strategies in order to perform well in the translational exercise. Summarily, the research frameworks for this study are Nida's equivalence and Gottlieb's subtitle strategies.

\section{ReSEARCH MeTHOdOLOGY}

In line with the above information, there are different methods one can adopt in order to have a clear rendering. Many translation scholars have come up with different theories, techniques, principles and strategies in order to see that the transferred information is perceived original in the target language by the target audience. Based on this, the study shall adopt the emergent design approach in its methodology in studying the correctness of subtitled expressions in context: The translator in film making process in the film titled Onye Bu Nna M since this study is a qualitative research. The appropriateness of the design for the study is because, it adapts to new ideas that comes up in the course of carrying out a qualitative research. Also, the study shall adopt the methodology of explication in analyzing the data used for the study. The researcher shall play and replay the movie in order to make a fair judgment.

\section{OVER VIEW OF THE MOVIE ONYE Bu NNA $M$}

The movie was shot to reveal the decadence people show in their relationships. It addresses that one should take up his responsibilities. The movie entitled Onye Bu Nna M'is an Igboeze production movie of the Nollywood industry. It is a film that presents the need of a father in one's life. Chioma who was pregnant for Samuel gave birth to Amaka who was born outside wedlock in her father's house (Chioma's father). Samuel who the film revolves around was in a relationship with Nneka. Also, he is the one who got Chioma pregnant at their early age of life and equally denied being responsible for the pregnancy. In one of the occasions, Sam (Samuel) as he is usually called proposed to Nneka for marriage but was turned down. However, Sam moved on with his life. Afterwards Sam's proposal was pushed to bay, he got across Chioma and started making moves to make peace with her which he succeeded at last and they lived happily after whilst he assumes the role of a father to Amaka.

\section{Data PRESEntation AND ANALysis}

The data analysis is strictly done based on the objective of the study in order to get the actual result that is supposed of this research exercise. The objective is to ascertain the correctness of subtitled expressions in context: The translator in film making process. It will also use the Nida's equivalence and Gottlieb's strategy in the analysis. Based on this, the analysis will be done in the tables 1 - 3 below. 
TABLE I

SHOWING THE USE OF TRANSFER IN ONYE Bu NNA $M$

\begin{tabular}{|c|c|c|}
\hline Asụsụ Igbo & Movie English Language subtitle & Correct expressions in context \\
\hline $\begin{array}{l}\text { I were ego maọbụ ihe ọ bụla nye amụnsụ, I } \\
\text { korola okwu }\end{array}$ & $\begin{array}{l}\text { Shoukd you offer mony or any other thing } \\
\text { to a wizard you've invite trouble }\end{array}$ & $\begin{array}{l}\text { If you give money or anything to a witch, you } \\
\text { have brought problem on yourself }\end{array}$ \\
\hline $\begin{array}{l}\text { ọkwa ị mara nwata nwanyị a dị ọcha na- } \\
\text { aga achọta m toro ogologo? }\end{array}$ & $\begin{array}{l}\text { Do you know that very young girl that do } \\
\text { visit me } \S\end{array}$ & $\begin{array}{l}\text { Do you know the tall and fair complexioned } \\
\text { young girl that visits me? }\end{array}$ \\
\hline $\begin{array}{l}\text { Ya ka o nọkatara last week nwata nwanyị } \\
\text { a wee buru onwe ya bịa. }\end{array}$ & Just last week the girl showed up & Just on a sudden last week, the girl came visiting \\
\hline $\begin{array}{l}\text { A na-ekwu ka a na-ekwu, nwata nwanyị } \\
\text { nọrọ n'elu bed pịwa phone }\end{array}$ & $\begin{array}{l}\text { Just in same time the girl started browsing } \\
\text { through phone in bed }\end{array}$ & $\begin{array}{l}\text { Without wasting time, the girl climbed the bed } \\
\text { and started pressing phone }\end{array}$ \\
\hline $\begin{array}{l}\text { Ihe m na-akọgheri bụ adịm ime. o kwa ihe } \\
\text { m na-agwa gị na mụ achọghị ka o mee }\end{array}$ & $\begin{array}{l}\text { The rubbish am talking is that am pregnant } \\
\text { Same thing I was warning you I wouldn't } \\
\text { like to happen }\end{array}$ & $\begin{array}{l}\text { The rubbish that I am talking about is that I am } \\
\text { pregnant. It is what I was telling you that I would } \\
\text { not want to happen }\end{array}$ \\
\hline $\begin{array}{l}\text { Onweghi ihe } \mathrm{m} \text { mere. } \mathrm{O} \text { nweghi ihe } \mathrm{m} \\
\text { mara } \mathrm{m} \text { mee gi }\end{array}$ & $\begin{array}{l}\text { I don't know what I did. I don't know if I } \\
\text { did anything to you }\end{array}$ & $\begin{array}{l}\text { I did not do anything; there is nothing I knew that } \\
\text { I did to you. }\end{array}$ \\
\hline $\begin{array}{l}\text { A na-ekwu okwu love o na-ekwu okwu } \\
\text { ring }\end{array}$ & Talking love he's talking ring & $\begin{array}{l}\text { While talking about love, you are talking about } \\
\text { ring }\end{array}$ \\
\hline \multirow[t]{2}{*}{$\begin{array}{l}\text { Mụ na ezinaụlọ m na ndị be anyị na-adị gị } \\
\text { ka ndị ara }\end{array}$} & $\begin{array}{l}\text { I and my family all seem to you like crazy } \\
\text { ones }\end{array}$ & $\begin{array}{l}\text { I and my family as well as my people seem to } \\
\text { you like mad people. }\end{array}$ \\
\hline & SEASON TWO & \\
\hline $\begin{array}{l}\text { Mụ gaghị achọ m pụta n’ezi m hụ gị na } \\
\text { ụmụnwoke na-akwụgharị }\end{array}$ & $\begin{array}{l}\text { I wouldn't want seeing you roaming about } \\
\text { with men }\end{array}$ & $\begin{array}{l}\text { I will not want to come outside and see you and } \\
\text { boys perambulating. }\end{array}$ \\
\hline Amaka biko ewela iwe o, ezi enyi $\mathrm{m}$ & $\begin{array}{l}\text { amaka please don't get annoyed over what I } \\
\text { just said }\end{array}$ & $\begin{array}{l}\text { My good friend Amaka, please don't be angry } \\
\text { again. }\end{array}$ \\
\hline
\end{tabular}

The translator uses the transfer strategy to achieve his aim. This method is involved with translating the source text completely and accurately without meaning loses in the target language. A clear explication of the embodiments of what transfer connotes can be seen in the table above. The used strategy also aligns with the view of Nida's theory of equivalence. Equivalence is involved with having the same information of the original in another language without meaning lose.

TABLE II

SHOWING THE USE OF PARAPHRASE AND IMITATION IN $O N Y E B u$ NNA $M$

\begin{tabular}{|c|c|c|}
\hline Asụsụ Igbo & English Language subtitle & Correct expressions in context \\
\hline $\begin{array}{l}\text { Chere Nneka, ị dịkwa serious n'ihe } \\
\text { a ị na-ekwu? }\end{array}$ & $\begin{array}{l}\text { Wait Nneka so you're actually serious about } \\
\text { what you're are saying } \S\end{array}$ & $\begin{array}{l}\text { Wait, are you actually serious with what you are } \\
\text { saying Nneka? }\end{array}$ \\
\hline \{ na-ege $\mathrm{m}$ ntị? & Are you listening $\S$ & Are you listening to me? \\
\hline $\begin{array}{l}\text { Maka a piwakwaraa ihe a, uche ha } \\
\text { apụo }\end{array}$ & $\begin{array}{l}\text { Cos once they start that chatting they lose } \\
\text { concentration }\end{array}$ & $\begin{array}{l}\text { Because they lose concentration once they start } \\
\text { chatting, }\end{array}$ \\
\hline Sam, ya oteela I mewere? & Sam its long you've been doing? & So, it has been long you started doing it Sam? \\
\hline Nwanne gị nwoke asịiọ gị, ị sị ya . & If your does not say to you you'll say to him & $\begin{array}{l}\text { If your brother does not say to you, you will say to } \\
\text { him. }\end{array}$ \\
\hline $\begin{array}{l}\text { Ngwanụ biko ka anyị mee sọsọ otu } \\
\text { or ka anyị mee half, sọ sọ half }\end{array}$ & $\begin{array}{l}\text { Ok then. Please, just once Or lets do half. Just } \\
\text { half }\end{array}$ & Ok, please let us do it once or we do half, just half. \\
\hline Kee ihe ị sịrị na ọ bụ ya na-eme gị? & What did say is wrong with you? & What did you say that is happening to you? \\
\hline $\begin{array}{l}\text { Ahụkwara m gị n'anya, o bụghị } \\
\text { ring ga-ebutere mụ na gị esemokwu }\end{array}$ & $\begin{array}{l}\text { I love you. its not ring that should bring us } \\
\text { quarrel }\end{array}$ & $\begin{array}{l}\text { It's not ring that will bring quarrel between us, I } \\
\text { loved you }\end{array}$ \\
\hline Maka ị ma na ọ ga-akago aka & Cos you know she must've matured & Because you know that she must be mature by now \\
\hline Maka ụdị ọsọ o gbaa taa & Cos the way she ran today & Because the way she ran today \\
\hline $\begin{array}{l}\text { O nwere onye I na-ele anya ya ga- } \\
\text { achọta gị n'abali a? }\end{array}$ & Are you expecting a visitor tonight $\S$ & Are you expecting anybody to visit \\
\hline $\begin{array}{l}\text { Gaa mara onye bụ ihe ahụ na-akụ } \\
\text { aka }\end{array}$ & Go check to know who's that knocking & Go and check the person that is knocking \\
\hline $\begin{array}{l}\text { Ihe nke a pụtara bụ na mụ } \\
\text { aghọtaghị agwa gị nke ikpe azụ a }\end{array}$ & $\begin{array}{l}\text { What this means, is that I don't understand } \\
\text { your behavior this lastly }\end{array}$ & $\begin{array}{l}\text { What this implies is that I do not understand your } \\
\text { behaviour lately }\end{array}$ \\
\hline Esisielam nri, bịa ka ị bịa rie nri & I'm done cooking. Come have dinner & Come and eat food, I am through with cooking \\
\hline $\begin{array}{l}\text { ọ bưrụnụ ring ka ị chọrọ, ring juru } \\
\text { n'ime ahịa, m jee ahịa m kpote ring } \\
\text { mkponye gị }\end{array}$ & $\begin{array}{l}\text { If it is ring you want there are uncountable of } \\
\text { it in the market when go to market I ll get you } \\
\text { enough of it }\end{array}$ & $\begin{array}{l}\text { When I go to the market, I will get you enough of it. } \\
\text { If it is ring that you want rings are much in the } \\
\text { market. }\end{array}$ \\
\hline $\begin{array}{l}\text { Ajụọla m gị, mmadụ abụọ nwere } \\
\text { temper problem, ha a na-anọ n'otu } \\
\text { ụlọ? }\end{array}$ & $\begin{array}{l}\text { Does two people that with temper problem } \\
\text { stay in one house } \S\end{array}$ & $\begin{array}{l}\text { I have asked you; do two people with temper problem } \\
\text { stay in one house? }\end{array}$ \\
\hline $\begin{array}{l}\text { Ihe m chọrọ kịtaa bụ etu mụ na nwa } \\
\text { m nwanyị ga-eji na-adị na mma }\end{array}$ & $\begin{array}{l}\text { The only thing I want right now is how be in } \\
\text { good terms with my daughter }\end{array}$ & $\begin{array}{l}\text { The thing I wanted right now is how I will be in good } \\
\text { terms with my daughter. }\end{array}$ \\
\hline $\begin{array}{l}\text { Otu ụbọchị isi na ntị onye oozọ nụ na } \\
\text { ada gị nwanyị na-agba nkwụ }\end{array}$ & $\begin{array}{l}\text { One day, you'll hear from someone else that } \\
\text { your daughter is having her traditional } \\
\text { wedding }\end{array}$ & $\begin{array}{l}\text { One day, you will hear from someone else that your } \\
\text { daughter is having her traditional marriage. }\end{array}$ \\
\hline Bịa, lee $m$ anya & Come, look & Come, look at me. \\
\hline
\end{tabular}




\begin{tabular}{|c|c|c|}
\hline $\begin{array}{l}\text { Kee ka ị ga-esi ebe isi tiri bata bịa } \\
\text { na-achọ onye ga-enye gị ugwu? }\end{array}$ & $\begin{array}{l}\text { How can you just from wherever barge in here } \\
\text { looking for who will give you respect } \S\end{array}$ & $\begin{array}{l}\text { How will you just come from anywhere and start to } \\
\text { look for one who will respect you? }\end{array}$ \\
\hline $\begin{array}{l}\text { M ka ga-abịa hụ gị. o kwanụ ọrụ, } \\
\text { ọụ karịrị m ahụ, biko ewela iwe }\end{array}$ & $\begin{array}{l}\text { I will still come and see you its just work I am } \\
\text { very much occupied with work please do not } \\
\text { be angry }\end{array}$ & $\begin{array}{l}\text { It is just work, I have too much work, don't be angry } \\
\text { please, I will still come and see you }\end{array}$ \\
\hline $\begin{array}{l}\text { Etu m si were hụ ya bụ nwa, o } \\
\text { nwekwara mwute na ụdị akwa o } \\
\text { bere ebe a }\end{array}$ & $\begin{array}{l}\text { The way am looking at that man he's deeply } \\
\text { pained cos the way he cried here today }\end{array}$ & $\begin{array}{l}\text { The way I see that boy, he was remorseful as well as } \\
\text { the way he cried here }\end{array}$ \\
\hline \multirow[t]{2}{*}{ Atarọ $\mathrm{m}$ gị } & I do not blame & I do not blame you \\
\hline & SEASON TWO & \\
\hline $\begin{array}{l}\text { o na-abụkwaraa I kwuwe ihe dị etu } \\
\text { a, ọ na-echetara ihe m chezọrọ } \\
\text { echezọ }\end{array}$ & $\begin{array}{l}\text { Each time you say things like this it reminds } \\
\text { me of things I've long forgothen }\end{array}$ & $\begin{array}{l}\text { Once you start saying things of this kind, it reminds } \\
\text { me of the things I have long forgotten }\end{array}$ \\
\hline $\begin{array}{l}\text { ọkwanụ otu afọ fọrọ ka } \mathrm{m} \text { si na } \\
\text { mahadum pụta }\end{array}$ & $\begin{array}{l}\text { Is it not just one year left and I will graduate } \\
\text { from the university } \S\end{array}$ & $\begin{array}{l}\text { It is just a year that remains for me to graduate from } \\
\text { the university. }\end{array}$ \\
\hline Ka m gwa gị nke na-eme eme & Let me tell you what do happen & Let me tell you the happening information \\
\hline $\begin{array}{l}\text { Uncle Sam sị na ọ ga-azụtara m ji a } \\
\text { hụrụ ahụ na mmanụ ma ọ na-abịa }\end{array}$ & $\begin{array}{l}\text { Uncle Sam saids he will bring me roasted yam } \\
\text { while coming }\end{array}$ & $\begin{array}{l}\text { Uncle Sam said that he will buy for me a roasted yam } \\
\text { and red oil while coming }\end{array}$ \\
\hline $\begin{array}{l}\text { Gị na Uncle Sam nke a. ị dị sure na } \\
\text { ọ bụghị ya bụ nna gị? }\end{array}$ & $\begin{array}{l}\text { and you're now happy. are you sure uncle Sam } \\
\text { is not your father } \S\end{array}$ & $\begin{array}{l}\text { You and this uncle Sam. Are you sure he is not your } \\
\text { father? }\end{array}$ \\
\hline ọ etu unu si eme dịka nna na nwa & $\begin{array}{l}\text { It just because of the closeness between you } \\
\text { both }\end{array}$ & $\begin{array}{l}\text { It is because of the way you people behave as father } \\
\text { and daughter }\end{array}$ \\
\hline $\begin{array}{l}\text { Uju nekwaa anya ka m gwa gị, e } \\
\text { nwere ihe e ji egwu egwu nwee ihe } \\
\text { ejighi egwu egwu.. }\end{array}$ & $\begin{array}{l}\text { Uju look let me tell you. they're things you } \\
\text { joke with and they're things you don't joke } \\
\text { with also }\end{array}$ & $\begin{array}{l}\text { Uju look let me tell you, there are things one plays } \\
\text { with and things one doesn't play with }\end{array}$ \\
\hline $\begin{array}{l}\text { Ka a kpogodu nke a egwuregwu. } \\
\text { Anwakatakwala anwa n'ụwa a } \\
\text { again were ụdị ihe a wee gwusa m } \\
\text { egwu ọzọ }\end{array}$ & $\begin{array}{l}\text { For today lets call it a joke. Next don't you } \\
\text { ever try this kind of joke again. }\end{array}$ & $\begin{array}{l}\text { Let us just call this one a play. Never you in this life } \\
\text { use this kind of thing to play with me again }\end{array}$ \\
\hline
\end{tabular}

Looking at the frames - subtitles, you will discover that it is full of rephraseology and imitation of the original information in order to be faithful with the information. So, paraphrase is resorted to in cases where the phraseology of the original language cannot be reconstructed in the same syntactic way in the target language while imitation maintains the same forms, typically with names of people and places unaltered. So the formness retention is almost in alignment with Nida's view of dynamic equivalence where his focus is on form and content. Extracts from the table above explicates the rendition of the frames hence, subtitles.

TABLE III

SHOWING THE USE OF EXPANSION IN ONYE Bu NNA $M$

\begin{tabular}{|l|l|l|}
\hline Asụsụ Igbo & English Language subtitle & Correct expressions in context \\
\hline o sịị ka ọ kwụnye bulb? & He said he wants to plug in bulb & He said that he wants to have sex \\
\hline $\begin{array}{l}\text { f tara akwụ ka etu a ka eze gị si } \\
\text { acha? }\end{array}$ & $\begin{array}{l}\text { Did you chew palm-fruit or is this the colour } \\
\text { of your teeth § }\end{array}$ & Are you ok? \\
\hline $\begin{array}{l}\text { Maka o nwaa ya anwaa,m kuru } \\
\text { mmiri ọnwaụ che ya }\end{array}$ & Cos if he dares it, I'll give him death water & Because if he tries it, I will kill him \\
\hline
\end{tabular}

The used strategy in the above table tries to make explicit the original information to the target audience. It tries to explain utterances. In other words, it defines the utterances used in the source video. The strategy is expansion. So, an expansion is used when the original text requires an explanation because of some cultural nuances not retrievable in the target language. When the right information is being tendered wrongly, the grammar may give false information. So, wrong expression in context actually gives a negative thought to the intended message. Due to inappropriate expression of the intended information of the source language due to wrong use of verb, adjective and adverb or other word classes, the supposed information tends to be missed in the process. On the contrary, the good expression of thoughts gives credit to the information that is meant for the target audience. In subtitle based on the little time that is used to read up the frames on the bottom part of the screen or cinema, a good subtitle will require a short time for the information to be digested easily, when the right terms are used with the right tenses, concords, grammatical constructions and all the rudiments that make up a sentence.

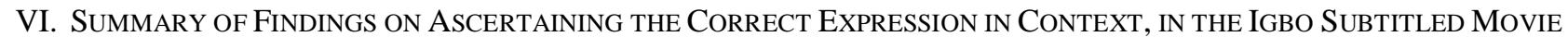

The language of the world operates with different syntactic and grammatical contrasts, and its right use brings about good semantic contrasts. In this study, it is discovered that grammar can be seen as a general rule that governs languages of the world while phonotactics deals strictly on a particular language. This is to say that the rule that is obtainable in phonotactics is language specific. However, it is discovered that expression is used to denote spoken or written utterances while the focus of this segment is on the correct expression in context of the movie used for the study. It looked at how well the subtitled information is rendered in the target language. The study reveals that the source language of the film used for the study is Igbo while the target language is English language. So, in order to have 
accuracy in the different terms and phrases of the source information to the target based on the right expressions used in context, the study finds out that different languages are used throughout the world to communicate ideas, beliefs, intentions, actions and feelings. It also discovered that with mass media and the internet, interaction is occurring faster and more frequently with every passing second. The study showed that a wrong expression used in context of discourses brings about change in communication of ideas, beliefs, intentions, actions and feelings in the subtitled Igbo movie used for the study and other areas where grammar use can be applied. Based on this, the study claims that if information is written well with the right tenses by observing the right phonotactics of that language, there will be no misinterpretation of ideas or information, and on this, the objective of this study is achieved. This is because, the study has actually ascertained the right expressions used in context, in the Igbo subtitled movie used for the study. It has equally given its signification on the insight translators can follow when faced with subtitle of this kind.

\section{A. Conclusion}

Due to the discrepancies between the two languages of discourse, the nature of subtitling in the Igbo films are critically analysed carefully. So, looking at the totality of the study, the research shows that translation is not just an interlinguistic process of information used or transferred, but a more complex exercise which is more than just replacing a source language text with a target language text. On this note, it is worthy to state that out of the findings of the study, it is discovered that the major or ultimate constraint or problem on the subtitles arise from the fact that it is an overt form of translation in the sense that it can be assessed and evaluated by anyone who knows the source language of the movie used for the very information under discourse. However, following the strategy of Gottlieb (1992), the subtitle strategies shows that the constraints that operate in the process of subtitling result in a greater degree of loss than it is the case in other types of transfers. Based on this, it can be said that the findings of this study have taken the gaps that prompted this study to the limelight in going a long way in solving the problem of the study. The adopted frameworks that are used for the study is suitable. For Gottlieb's (1992) subtitle strategies, it went far in capturing the various subtitling strategies employed by the translators of the Igbo films used for the study. The study also uses three tables for the study and finally concludes that the study has left no stone unturned.

\section{B. Recommendations}

In the future based on this research conducted in ascertaining the correct expression in context, in the Igbo subtitled movie, the researcher recommends that further researches should be done in audiovisual productions in Igbo language which in the course of the study, the exercise will look at dubbing and subtitles in Igbo. Again, the quality of subtitles of the Igbo home made movies that its focus is on the target audience should be investigated. This will be on the basis that the information meant for a particular group must conform to their belief systems and ideologies of the people so that it will be embraced by the target audience. This is also in alignment with Nida's proposition on sameness in the sense that any translational piece is said to be equivalent only if the effect, which the source text has on its readers are also achieved on the target readers.

\section{REFERENCES}

[1] Aderinokun, T. (2005). The economics of Nigerian film, art and business. [Online]. Retrieved October 16, 2019, from: http://www.nollywood.net/Essays/p2_articleid/26

[2] Bilal K. K. (2016). An introduction to subtitling: Challenges and Strategies. International Journal of Comparative Literature and Translation Studies, 3(1). Retrieved 26 November, 2020, $122-124$

[3] Christopher, R. (2014). The interpreter and translator trainee. The subtitle Project, 2(1). Doi:10.1080/1750399x.2008.10798768.

[4] Gottlieb, H. (1992). Subtitling a new university discipline. In Dollerup, C. \& Loddegaard, A. (Eds.), Teaching translation and interpreting: training talent and euperience: papers from the first language international conference, Elsinore, Denmark, 161170.

[5] Magdalene, O. \& Agnieszka, S. (2020).The quality of templates in subtitling: A survey on current market practices, and changing subtitler competences. Perspective. Doi.org/10.1080/0907676ụ.2020.1791919. Retrieved August 8, 2020.

[6] Nida, E. A. (1964). Toward a science of translation. Leiden: Brill

[7] Nwatu, R. G. (2017). Subtitling in some selected Igbo musical videos. M. A Dissertation, Department of Linguistics, University of Nigeria, Nsukka.

[8] Nwike, C. C. (2015). Usoro na nsogbu a na-enwe na ntụgharị \{duuazị: Chike and river dịka ebe mgbakwasị ụkwụ. B. A. Project, University of Nigeria, Nsukka.

[9] Nwike, C. C. (2019). Issues and challenges in translating legal text from English to the Igbo language. M. A Dissertation, Department of Linguistics, University of Nigeria, Nsukka.

[10] Tim, Z., Wilfried, A., Fred, P. \& Nadira, S. (2017). Effect of subtitles, complexity and language proficiency on learning from online education videos. Journal of Media Psychology Theories, Method and Application 29(1) Doi:10.1027/1864$1105 / 900208$.

[11] Uchenna, O. (2007). Nollywood: The influence of the Nigerian movie industry on African culture, Retrieved January 1, 2020 from https://scholar.google.com/citations?user=xCh6NzoAAAAJ\&hl=en. 


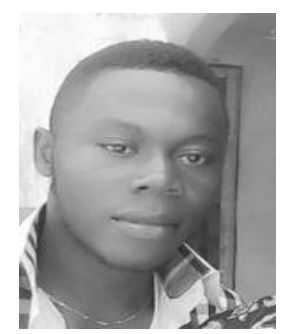

Christopher C. Nwike is a native of Onitsha, Onitsha North Local Government Area of Anambra State. He was born in Ogidi, Anambra State on the $3^{\text {rd }}$ of May. Christopher C. Nwike obtained a Bachelor of Arts degree in Linguistics/Igbo in the department of Linguistics, Igbo and Other Nigerian Languages, University of Nigeria, Nsukka Enugu State in 2015. Also, he obtained a Master of Arts degree in Translation in the department of Linguistics, Igbo and Other Nigerian Languages, University of Nigeria, Nsukka Enugu State in 2019. Currently, Christopher C. Nwike undergoes a doctoral study (PhD) in Translation in the department of Linguistics, Igbo and Other Nigerian Languages, University of Nigeria, Nsukka.

He engages in translation jobs - textual translation and subtitles. He is an Igbo language teacher in Royal Crown Academy Orba Road Nsukka, Enugu State.

Mr. Nwike belongs to the Association of Translation Studies in Nigeria. He also obtained an academic merit award in Honour of Aknu-ibiam As the Best Graduating Student Who Produced the Best Long Easy in Igbo Language in the 2014/2015 Academic Session.

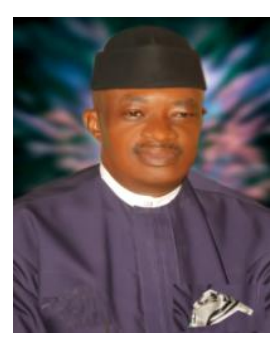

Christopher Uchenna Agbedo was born and brought up in Olido, Elugwu-Ezikeoba, Igbo-Eze North Council Area of Enugu State Nigeria. He studied in the Department of Linguistics and Nigerian Languages, University of Nigeria Nsukka and obtained B.A (Linguistics/Igbo), M.A (Linguistics), PhD (Linguistics) in 1986, 1991 and 1997 respectively. He has been a key player in the university system as a lecturer, supervisor, researcher, mentor, administrator, language development expert and communication strategist, consultant to professional and corporate bodies like National University Commission, National Commission for Colleges of Education, and Joint Admission and Matriculation Board. He is a member of the Senate of the University of Nigeria, member, Senate Entrance Committee, chairman and member of several University, Faculty, and Departmental Committees. He is a Professor of Linguistics, and was immediate past Head of Department, Linguistics, Igbo \& Other Nigerian Languages, University of Nigeria, Nsukka Nigeria. Prof Agbedo has authored over 100 publications, comprising 9 mainline textbooks on language and linguistics, 4 creative works (novels), 80 journal articles, 16 book chapters and 2 edited books and journals. He is a member of professional organisations, including Linguistic Association of Nigeria, Applied Linguistics and Literacy in Africa \& the Diaspora Research Network, American Association for Applied Linguistics, International Pragmatics Association, African Studies Global Virtual Forum, Pennsylvania State University, USA and Fellow, Netherlands Institute of Advanced Studies (NIAS-KNAW). He has attended over 28 local, national, and international conferences, seminars, and workshops. He has successfully supervised over 100 undergraduate long essays, 38 Master of Arts dissertations, and 19 doctoral theses. He is an external examiner to over 10 federal and state universities and external assessor of professorial appointments to several federal and state universities. He is currently on the editorial boards of about 10 local and international journals as founding editor, editor-inchief, editorial consultant, and peer review editor. He has 10 local and international prizes and awards. His areas of specialisation are sociolinguistics and psycholinguistics; his research interests include critical applied linguistics, pragmatics, discourse analysis, translation/interpretation, child communication disorders and documentary linguistics. 